US medical research healthy

\section{London}

A RECENT report suggesting that US clinical research is in decline because of shortfalls in funding is misleading, according to the editors of leading medical journals.

In the 15 March issue of the New England Journal of Medicine (322, 739-742; 1990), Thomas and Sage Stossel, from the Massachusetts General Hospital, show that original research papers with at least one US author became progressively scarcer between 1978 and 1988. But clinical research in other parts of the world has been on the rise (see figure). Although reluctant to draw firm conclusions from this, the researchers suggest that the drop "coincides with the slowed growth of funding from the National Institutes of Health for US clinical research".

But editors think otherwise. Stephen Lock, editor of the British Medical Journal $(B M J)$, says that the report is "simplistic" because it does not account for subtle shifts in editorial direction that may influence a researcher's choice of journal. Lock's impression is that US research is as healthy as ever, but each journal presents a special case. For example, the fact that the $B M J$ is British "puts Americans off". Not that this deters researchers from Japan or continental Europe, in particular Scandinavia. So US appearances in the $B M J$, at least, may be more a function of national attitude than research acumen.

Gordon Reeves, editor of the Lancet, agrees: like Lock, he highlights Scandinavia as a brightening focus of excellent medical research, but says to suggest a decline in US research would be misleading.

According to the report, published papers with no US input have maintained a steady presence in the Lancet for the past decade, whereas US papers have become fewer, declining from a peak of 139 in 1980 to only 32 in 1987 . But Reeves

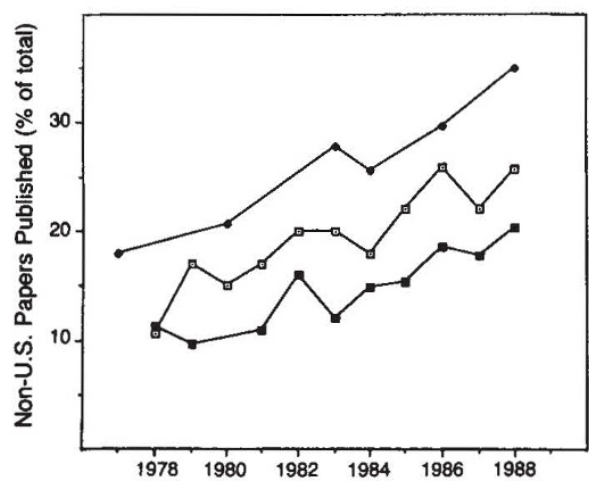

Non-US papers published by the New England Journal of Medicine (open squares), the Journal of Clinical Investigation (solid squares) and Blood (diamonds), 1977-88. (Reprinted by permission of the New England Journal of Medicine 322. 739; 1990) expects a revival of US research papers in the Lancet following an increase in US subscriptions and the establishment, this year, of a US office close to the National Institutes of Health in Maryland.

Even if US medical research is really on the slide, says Lock, the causes may be more complex than a simple decline in funding. German medical research was paramount before the Second World War, he says, and Viennese work before that. The quality of Japanese and European research is in the ascendant for a variety of reasons, says Lock, and US research could be past its peak. But for the moment, at least, reports of its imminent demise have been exaggerated.

David Pendlebury of the Philadelphiabased Institute for Scientific Information (ISI) and editor of Science Watch is concerned about the choice of journals sampled by the Stossels. He questions the inclusion of the British-dominated
Lancet, and regards the omission of Journal of the American Medical Association (JAMA), as a major flaw. In a survey of the ISI's databases, carried out for Nature, and reviewing a wider selection of medical journals, Pendlebury finds little evidence for a marked decline in publications featuring a US author over the 1980s (although he stresses that his own survey includes a wider range of contributions than original research articles alone).

Pendlebury does note a decline in the percentage of papers in the JAMA with US authors, from 84.3 per cent in 1981 to 64.2 per cent in 1989 , mostly due to a decline in the early 1980 s. But he says it is difficult to interpret this trend.

George Lundberg, editor of the JAMA, says the American Medical Association says that preliminary results of a survey of papers submitted to, and published in, its journals suggest that the number of US submissions and their acceptance rate have been "pretty stable" over the last several years.

Henry Gee \& Peter Aldhous

\title{
No to fortress Europe
}

\section{London}

THE Royal Society has warned against adopting a 'fortress Europe' attitude towards Britain's future international collaborations in science. Professor Anthony Epstein, the society's vicepresident, told the House of Commons Education, Science and Arts Committee that Britain should foster scientific contacts with East European countries, and not concentrate just on projects within the European Communities (EC).

World science has three 'gravitational centres' - the United States, Japan and Europe - Epstein said, and if Europe is to compete, Eastern European manpower and expertise should be drawn upon.

The EC's funding of science through its Framework programme may, in any case, be flawed, according to Epstein. He said the programme suffered through its rigid direction from the European Commission and strong bias towards applied research.

The lack of adequate peer review, Epstein suggested, may also mean that Framework-funded projects are inferior to those supported at the national level. The society's written evidence to the committee nominates the Strasbourgbased European Science Foundation (an association of European research councils and academies) as a candidate for the peerreview task, with Academia Europea providing further advice. But Epstein said that this would need a substantial diversion of EC funds to the two bodies.

Peer review typically takes up only 1 per cent of a science budget, Epstein said, but in the context of the Framework programme's five-year budget of 5,400 million ECU, this is a large sum.

British national science policy also limits the effectiveness of British scientists' involvement in EC-funded science, according to the society's witnesses. Sir Eric Ash, rector of Imperial College, London, said that, unlike institutions in many other EC countries, British universities receive no funds to cover overheads arising from EC projects. Ash likened the effects of accepting an EC grant in financially squeezed British universities to "drinking seawater when dying of thirst". Epstein added that financial stringency meant that British universities often have to charge 'bench fees' to visiting scientists from abroad.

Not surprisingly, Epstein pointed to the Royal Society's own exchange schemes as a role model for international cooperation. The society is a small-money player in international terms, but spends nearly 30 per cent of its annual budget from the Department of Education and Science on international collaboration.

Epstein explained that the Hungarian Academy of Sciences is to join the Royal Society's European Science Exchange Programme, and discussions are under way with the Polish Academy. He stressed the importance of the society's concentration on exchanges at the postdoctoral level. Britain should promote exchanges with East European scientists in their formative years, Epstein said, not visits from "70 year-old academicians".

Peter Aldhous 